\title{
Assessment of the Chemical Diversity and Potential Toxicity of Benthic Cyanobacterial Blooms in the Lagoon of Moorea Island (French Polynesia)
}

\author{
Isabelle Bonnard ${ }^{1}$, Louis Bornancin ${ }^{1}$, Klervi Dalle ${ }^{1}$, Mireille Chinain ${ }^{2}{ }^{(D}$, Mayalen Zubia ${ }^{3}$, \\ Bernard Banaigs ${ }^{1}$ and Mélanie Roué ${ }^{4, *(D)}$ \\ 1 Université de Perpignan, USR CRIOBE, LabEx CORAIL, 66860 Perpignan, France; \\ bonnard@univ-perp.fr (I.B.); louis.bornancin@wanadoo.fr (L.B.); klervi.dalle@gmail.com (K.D.); \\ banaigs@univ-perp.fr (B.B.) \\ 2 Institut Louis Malardé, UMR EIO, Papeete 98713, Tahiti, French Polynesia; mchinain@ilm.pf \\ 3 Université de Polynésie Française, UMR EIO, LabEx CORAIL, 98702 Faa'a, Tahiti, French Polynesia; \\ mayalen.zubia@upf.pf \\ 4 Institut de Recherche pour le Développement, UMR EIO, LabEx CORAIL, Faa'a 98702, Tahiti, \\ French Polynesia \\ * Correspondence: melanie.roue@ird.fr
}

Received: 10 April 2020; Accepted: 28 May 2020; Published: 4 June 2020

\begin{abstract}
In the last decades, an apparent increase in the frequency of benthic cyanobacterial blooms has occurred in coral reefs and tropical lagoons, possibly in part because of global change and anthropogenic activities. In the frame of the survey of marine benthic cyanobacteria proliferating in the lagoon of Moorea Island (French Polynesia), 15 blooms were collected, mainly involving three species-Anabaena sp.1, Lyngbya majuscula and Hydrocoleum majus-B. Their chemical fingerprints, obtained through high performance liquid chromatography combined with UV detection and mass spectrometry (HPLC-UV-MS) analyses, revealed a high extent of species-specificity. The chemical profile of Anabaena sp.1 was characterized by three major cyclic lipopeptides of the laxaphycin family, whereas the one of L. majuscula was characterized by a complex mixture including tiahuramides, trungapeptins and serinol-derived malyngamides. Toxicity screening analyses conducted on these cyanobacterial samples using Artemia salina and mouse neuroblastoma cell-based (CBA-N2a) cytotoxic assays failed to show any toxicity to a degree that would merit risk assessment with regard to public health. However, the apparently increasing presence of blooms of Lyngbya, Hydrocoleum, Anabaena or other benthic cyanobacteria on coral reefs in French Polynesia encourages the implementation of ad hoc monitoring programs for the surveillance of their proliferation and potential assessment of associated hazards.
\end{abstract}

Keywords: benthic marine cyanobacteria; blooms; tropical coral reefs; chemical fingerprints; toxicity

\section{Introduction}

Cyanobacteria are photosynthetic prokaryotes with a high morphological, physiological and metabolic diversity, with fossil records dating back to around 3 billion years ago [1,2]. They are widely distributed worldwide and are found in various habitats. Freshwater and brackish water cyanobacteria are well-known for their toxicity, with about 40 genera potentially producing cyanotoxins toxic to human beings and other vertebrates [3,4]. In contrast, marine cyanobacteria are well recognized as the potential producers of a variety of secondary metabolites that show a range of bioactivities potentially of interest for different industries, such as pharmaceutical, cosmetics, agriculture or energy [5-8]. In the last decade alone, estimations point to more than 400 newly described natural compounds, 
mainly peptides, extracted from marine cyanobacteria [8]. However, some marine cyanobacteria, like their freshwater and brackish water counterparts, can also produce potent toxins [3,9] and may thus represent a health hazard to human populations, for example, either through external exposure and skin irritation [10-12] or through consumption of fish or invertebrates having bioaccumulated toxins [13-16]. Besides these potential health impacts, marine benthic cyanobacterial blooms can also have negative consequences on coral reef health such as reducing coral settlement and recruitment [17], inducing coral diseases [18] or altering coral-associated microbial communities [19].

In recent years, reports of benthic cyanobacterial blooms have apparently increased in frequency in coral reefs and tropical lagoons, possibly in part in response to both man-made environmental disturbances and climate change [20,21]. As most of the areas where blooms are observed have importance for biodiversity, fish industry and tourism, the potential toxicity of benthic marine cyanobacteria has increasingly attracted the attention of the scientific community, environmental agencies and public health authorities. This is, for example, the case in Moorea Island (French Polynesia), where benthic cyanobacterial proliferations have been often observed during the warm season over the two past decades, especially in coral habitats degraded by anthropogenic activities (e.g., coastal development, tourism, fishing) [22]. Previous studies on these proliferating cyanobacteria mainly focused on the characterization of newly described bioactive metabolites in the filamentous cyanobacteria Lyngbya majuscula and Anabaena torulosa [23-27]. To the best of our knowledge, no harmful events for humans associated with these benthic cyanobacterial blooms have been reported so far in Moorea Island. In contrast, in Raivavae Island (Australes archipelago, French Polynesia), poisoning cases linked to the consumption of giant clams (Tridacna maxima) possibly contaminated with toxins produced by Oscillatoriales mats (Oscillatoria and Hydrocoleum genera) were reported [16]. In addition, the presence of the $s x t G$ gene fragment involved in the synthesis of saxitoxin (STX) was detected in two mats comprised of marine benthic filamentous cyanobacteria collected in Raivavae Island, suggesting that these cyanobacteria are able to synthesize STX or analogs (i.e., neurotoxins known to contribute to Paralytic Shellfish Poisoning in humans) [28].

The present study was conducted in parallel to the study recently published by Zubia et al. [22], in order to assess the chemical diversity and potential toxicity of some benthic cyanobacterial blooms collected in the lagoon of Moorea Island (Society archipelago, French Polynesia). To this end, the chemical fingerprints of organic extracts from benthic cyanobacterial blooms were acquired through high performance liquid chromatography combined with UV detection and mass spectrometry (HPLC-UV-MS) analyses, while their potential toxicity was evaluated using the Artemia salina (brine shrimp) lethality bioassay as well as the mouse neuroblastoma cell-based assay (CBA-N2a). This last assay was chosen because, combined with the use of particular compounds, it allows the specific detection of marine neurotoxins acting on voltage-gated sodium channels (VGSCs), such as ciguatoxins (CTXs) [29]. Indeed, previous studies have reported the potential production of CTX-like compounds by benthic marine cyanobacteria in New Caledonia and French Polynesia $[13,14,16]$. CTXs are neurotoxins produced primarily by benthic dinoflagellates belonging to the genera Gambierdiscus and Fukuyoa, the accumulation of which in coral reef fish and invertebrates in marine food webs is responsible for ciguatera poisoning, a food-borne disease with high incidence in French Polynesia [30]. Because ciguatera constitutes a major health issue and a major threat to food sustainability and food security for local populations in French Polynesia [31,32], the potential implication of benthic marine cyanobacteria in the ciguatera phenomenon needs to be assessed to adapt seafood poisoning risk monitoring and management programs if necessary. 


\section{Materials and Methods}

\subsection{Sampling and Species Identification}

Benthic cyanobacterial blooms $(n=15)$ were collected in various sites, mainly channels and sandy areas, of the lagoon of Moorea Island (Society archipelago, French Polynesia) (Figure 1) between October 2014 and March 2015. Each sample was geo-located and photo-documented in situ.

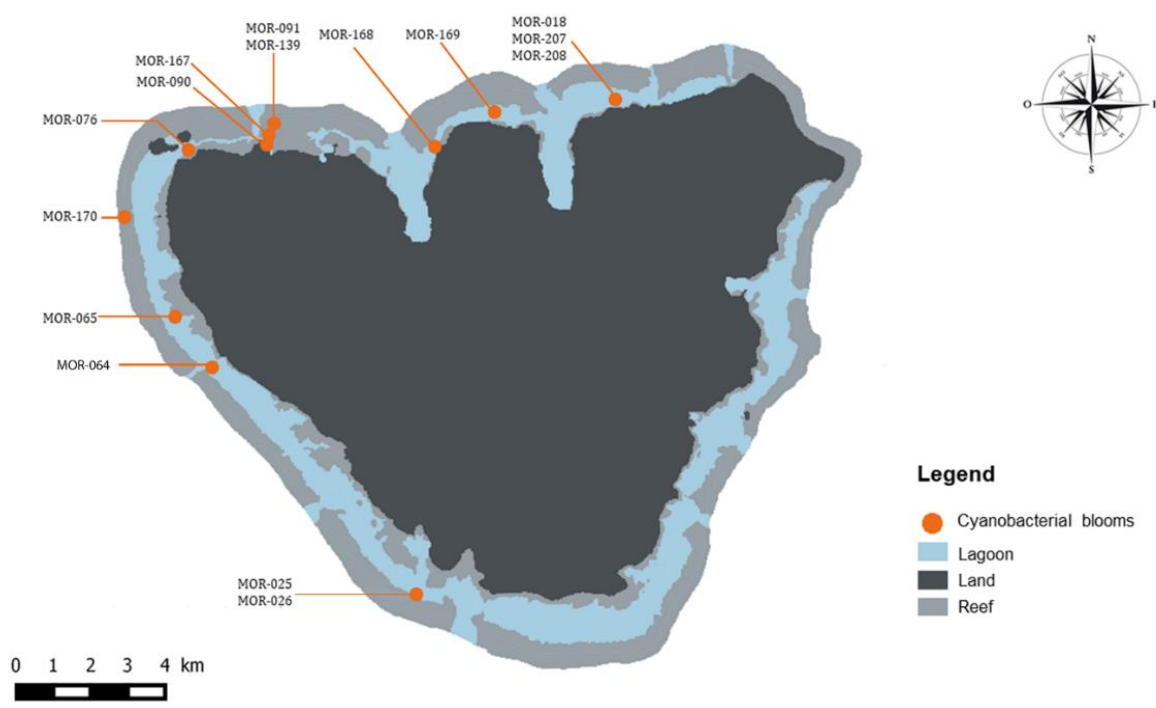

Figure 1. Map of Moorea Island showing the sampling sites of the 15 benthic cyanobacterial bloom samples analyzed in the present study.

In the field, two sub-samples of each bloom were immediately preserved for species identification - in 3\% solution of buffered formaldehyde in seawater for morphological analyses (light microscopy) and in guanidine thiocyanate for molecular analyses (16S rRNA gene fragments). The predominance of a given species in each bloom was verified under microscope. Samples were further analyzed for phenotype (i.e., species morphotype identification) and genotype (i.e., 16S rRNA sequences) determinations using a polyphasic approach previously described in Zubia et al. [22].

The remaining benthic cyanobacterial bloom samples were sorted to remove sand and epiphytes and quickly stored at $-20^{\circ} \mathrm{C}$ until freeze-drying before chemical and toxicological analyses.

\subsection{Metabolites Fingerprinting}

In order to capture a broad range of mid-polar and non-polar metabolites that can be used as chemotaxonomic markers, an extraction method with methanol $(\mathrm{MeOH})$ and dichloromethane $\left(\mathrm{CH}_{2} \mathrm{Cl}_{2}\right)$ was used. The chemical fingerprints of these organic extracts were then acquired by HPLC-UV-MS.

Freeze-dried samples ( $3 \mathrm{~g}$ ) were extracted three times in $20 \mathrm{~mL}$ of $\mathrm{MeOH}-\mathrm{CH}_{2} \mathrm{Cl}_{2}$ (1:1) under $5 \mathrm{~min}$ sonication. For each cyanobacterial sample, the resulting extracts were combined then evaporated under reduced pressure to give a greenish organic extract weighing between 90 and $200 \mathrm{mg}$, depending on samples. Next, 500 mg of RP-18 silica (Puriflash, $50 \mu \mathrm{m}$, Interchim, Montluçon, France) were added to each sample, previously dissolved in $\mathrm{MeOH}-\mathrm{CH}_{2} \mathrm{Cl}_{2}(1: 1)$, and the impregnated silica evaporated under reduced pressure was loaded on a C18-E solid-phase extraction (SPE) cartridge (Strata, 2 g, $12 \mathrm{~mL}, 55 \mu \mathrm{m}, 70 \AA$, Phenomenex, Torrance, CA, USA). After washing with water, the elution step was carried out with $\mathrm{MeOH}-\mathrm{CH}_{2} \mathrm{Cl}_{2}$ (1:1) to obtain desalted crude organic extracts. Finally, samples were prepared at a concentration of $1 \mathrm{mg} \mathrm{mL}^{-1}$ in $\mathrm{MeOH}$ and were filtered through Uptidisk filters (PTFE, $0.2 \mu \mathrm{m}$, Interchim, Montluçon, France).

The chemical fingerprints were acquired on a Thermo Fisher Scientific (Waltham, MA, USA) LC-MS device-an Accela HPLC coupled to a liquid chromatography quadrupole (LCQ) Fleet equipped 
with an electrospray ionization (ESI) source and a 3D ion-trap analyzer. The separation was achieved using a Gemini C6-Phenyl column $(150 \times 3.0 \mathrm{~mm}, 3 \mu \mathrm{m}, 110 \AA$, Phenomenex, Torrance, CA, USA), run at $30^{\circ} \mathrm{C}$, with a flow rate of $0.5 \mathrm{~mL} \mathrm{~min}^{-1}$ and a gradient solvent system programmed as follows-from 80:20 $\mathrm{H}_{2} \mathrm{O}$-acetonitrile $\left(\mathrm{CH}_{3} \mathrm{CN}\right)$ to $60: 40 \mathrm{H}_{2} \mathrm{O}-\mathrm{CH}_{3} \mathrm{CN}$ for $5 \mathrm{~min}$, from 60:40 to $30: 70 \mathrm{H}_{2} \mathrm{O}-\mathrm{CH}_{3} \mathrm{CN}$ for $25 \mathrm{~min}$, from $70 \%$ to $100 \% \mathrm{CH}_{3} \mathrm{CN}$ for $5 \mathrm{~min}$, then $100 \% \mathrm{CH}_{3} \mathrm{CN}$ held for $10 \mathrm{~min}$. All solvents were buffered with $0.1 \%$ formic acid $(\mathrm{HCOOH})$. Mass spectrometry acquisition parameters were as follows-positive and negative ion polarity, scan range from 150 to $2000 \mathrm{~m} / \mathrm{z}$, ionization voltage $-3 \mathrm{kV}$ or $4 \mathrm{kV}$ in ESI negative or ESI positive mode respectively, capillary temperature of $350{ }^{\circ} \mathrm{C}$ and sheath gas, sweep gas, auxiliary gas at 40, 2, 15 arbitrary units, respectively.

The identification of metabolites from L. majuscula and Anabaena sp.1 was made based on the retention times and masses of purified reference compounds-laxaphycins A, B, B3 [24,25] and tiahuramides A, B, C [26]. 1D/2D Nuclear magnetic resonance (NMR) spectroscopy and liquid chromatography-tandem mass spectrometry (LC-MS/MS) fragmentations were also used and the data were compared to those of known compounds-dolastatin 16 [33,34], serinol-derived malyngamides $4 \mathrm{a}$ and $4 \mathrm{~b}$ [35] and trungapeptins A-C [36] (Supplementary Material S1).

The chemical fingerprints of lipophilic fractions obtained with the extraction method described below (see Section 2.3) were also acquired (data not shown) and compared to those of $\mathrm{MeOH}-\mathrm{CH}_{2} \mathrm{Cl}_{2}$ extracts. Since only some minor differences in the relative number of peaks in the polar and mid-polar region of the chromatograms could be observed, only the chemical fingerprints of $\mathrm{MeOH}-\mathrm{CH}_{2} \mathrm{Cl}_{2}$ extracts were presented in the results Section 3.2. Since the LC-MS method used was designed to study mid- and non-polar secondary metabolites, the chemical fingerprints of the hydrophilic fractions obtained with the extraction method described below for the toxicological analyses (see Section 2.3) were not acquired and thus not shown.

\subsection{Evaluation of Cytotoxic Activity Using the Neuroblastoma Cell-Based Assay}

Before toxicological analyses targeting marine neurotoxins activating VGSCs, such as ciguatoxin-like compounds, benthic cyanobacterial samples were extracted according to the protocol previously described in Laurent et al. [16]. Thus, 5-10 g of each freeze-dried sample were extracted twice in $30 \mathrm{~mL}$ of $\mathrm{MeOH}$ and twice in $20 \mathrm{~mL}$ of $50 \%$ aqueous $\mathrm{MeOH}$, under sonication for $4 \mathrm{~h}$. Following centrifugation, the supernatants were pooled $(100 \mathrm{~mL})$ and dried under vacuum. The resulting dried extracts were further partitioned between $50 \mathrm{~mL}$ of $\mathrm{CH}_{2} \mathrm{Cl}_{2}$ and $2 \times 25 \mathrm{~mL}$ of $60 \%$ aqueous $\mathrm{MeOH}$. The resulting $60 \%$ aqueous $\mathrm{MeOH}$ and $\mathrm{CH}_{2} \mathrm{Cl}_{2}$ fractions, likely to contain hydrophilic and lipophilic toxic compounds, respectively, were dried under vacuum and stored at $4{ }^{\circ} \mathrm{C}$ until toxicological analyses.

The resulting lipophilic and hydrophilic fractions were screened for the presence of CTXs using CBA-N2a assay performed following the protocol previously described in Viallon et al. [37]. The final concentration for ouabain/veratridine treatment $\left(\mathrm{OV}^{+}\right.$conditions) was $85 / 8.5$ to obtain $90-100 \%$ of cell viability against control cells without ouabain/veratridine treatment ( $\mathrm{OV}^{-}$conditions). Each sample was tested in three independent experiments, with each concentration run in triplicate per plate. Lipophilic and hydrophilic fractions were tested using a serial dilution 1:2 of eight concentrations ranging from 74 to 9524 or 1475 to 188,783 pg dry extract $\mu \mathrm{L}^{-1}$, respectively. The maximum concentrations of dry extract (MCE) that does not induce non-specific cytotoxic effects on neuroblastoma (N2a) cells was estimated to be around $10 \mathrm{ng}$ dry extract $\mu \mathrm{L}^{-1}$ and higher than $190 \mathrm{ng}$ dry extract $\mu \mathrm{L}^{-1}$ for lipophilic and hydrophilic fractions, respectively. Absorbance data were fitted to a sigmoidal dose-response curve (variable slope) based on the four-parameter logistic model (4PL) allowing the calculation of half-maximal effective concentration $\left(\mathrm{EC}_{50}\right.$ ) values using Prism v6.07 software (GraphPad, San Diego, CA, USA). The $\mathrm{EC}_{50}$ values of samples were expressed in ng dried extract $\mu \mathrm{L}^{-1}$. According to Viallon et al. [37], samples inducing a loss of N2a cell viability between $50 \%$ and $80 \%$ at the MCE under $\mathrm{OV}^{+}$conditions were considered as weakly toxic.

Calibration of the assay was achieved using a P-CTX3C reference material sourced from the Institut Louis Malardé (Papeete, French Polynesia) that had been quantified gravimetrically. The $\mathrm{EC}_{50}$ value 
obtained for P-CTX3C was $3.1 \pm 0.8 \mathrm{fg} \mu \mathrm{L}^{-1}$. The toxin contents $(\mathrm{T})$ of samples were estimated

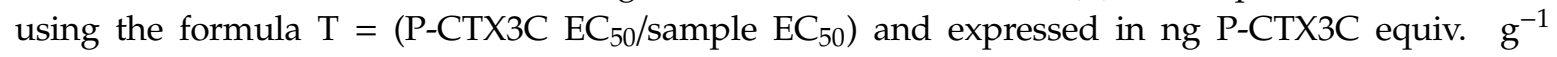
freeze-dried cyanobacteria.

\subsection{Evaluation of Toxicity Using Artemia salina Lethality Bioassay}

The evaluation of the toxicity of cyanobacterial bloom samples was also carried out using a brine-shrimp lethality assay $[38,39]$. Brine-shrimp eggs were hatched in seawater for $48 \mathrm{~h}$ at room temperature under constant light exposure. Hydrophilic and lipophilic fractions (obtained as described in Section 2.3) or methanol-dichloromethane desalted extracts (obtained as described in Section 2.2) were resuspended in dimethyl sulfoxide (DMSO) and diluted in seawater to give a final concentration of $100 \mu \mathrm{g} \mathrm{mL} \mathrm{g}^{-1}(1 \% \mathrm{DMSO})$. Negative controls containing only seawater and seawater $+1 \% \mathrm{DMSO}$ (final concentration) were also tested. Nauplii were transferred into 96-well microtiter plates (10 nauplii per treatment) filled with the test solutions and incubated at $25^{\circ} \mathrm{C}$ for $24 \mathrm{~h}$ under a $12: 12 \mathrm{~h}$ light regime. The experiments were conducted in triplicate for each sample. The mortality of animals (as indicated by lack of mobility) was recorded under a binocular magnifier. The percentage of lethality $(\% \mathrm{~L})$ was calculated by comparing the number of deaths in the test vs. control wells, using the following formula $-\% \mathrm{~L}=[($ Test - Control $) /(1-$ Control $)] \times 100$. Samples leading to a $\%$ L lower than $50 \%$ at a concentration of $100 \mu \mathrm{g} \mathrm{mL}^{-1}$ were considered as weakly toxic.

\section{Results and Discussion}

\subsection{Identification of Benthic Cyanobacterial Blooms}

The fifteen benthic cyanobacterial blooms sampled during the study were found to contain the following six species (Table 1)—Anabaena sp.1 (Figure 2A), Anabaena sp.2 (Figure 2B), Hydrocoleum majus-B (Figure 2C), Leptolyngbya sp.2 (Figure 2D), Lyngbya majuscula (Figure 2E) and Phormidium sp.1 (Figure 2F). Ten of these blooms appeared monospecific (i.e., predominated by one species), whereas the remaining five blooms were plurispecific mats (Figure 2G-H), composed mostly by three main species-Anabaena sp.1, Anabaena sp.2 and H. majus-B. The 16S rRNA gene fragments of seven monospecific bloom-forming cyanobacterial samples were successfully sequenced (Table S1). The detailed results and discussion on these taxonomical identifications are available in Zubia et al. [22]. None of the subsequent analyses were made at the population level.

Table 1. Identification of benthic cyanobacterial blooms collected in the lagoon of Moorea Island, according to Zubia et al. [22].

\begin{tabular}{cccc}
\hline Species Dominance & $\mathbf{N}^{\circ}$ Voucher & Latitude S & Longitude W \\
\hline \multirow{2}{*}{ Anabaena sp.1 } & MOR-076 & $17^{\circ} 29^{\prime} 26.60^{\prime \prime}$ & $149^{\circ} 54^{\prime} 40.50^{\prime \prime}$ \\
& MOR-139 & $17^{\circ} 29^{\prime} 13.20^{\prime \prime}$ & $149^{\circ} 53^{\prime} 24.20^{\prime \prime}$ \\
Anabaena sp.2 & MOR-167 & $17^{\circ} 29^{\prime} 19.46^{\prime \prime}$ & $149^{\circ} 53^{\prime} 28.32^{\prime \prime}$ \\
Hydrocoleum majus-B & MOR-207 & $17^{\circ} 28^{\prime} 47.63^{\prime \prime}$ & $149^{\prime} 48^{\prime} 27.78^{\prime \prime}$ \\
Leptolyngbya sp.2 & MOR-091 & $17^{\circ} 29^{\prime} 13.20^{\prime \prime}$ & $149^{\circ} 53^{\prime} 24.20^{\prime \prime}$ \\
& MOR-018 & $17^{\circ} 28^{\prime} 47.63^{\prime \prime}$ & $149^{\prime} 48^{\prime} 27.78^{\prime \prime}$ \\
Lyngbya majuscula & MOR-026 & $17^{\circ} 35^{\prime} 30.50^{\prime \prime}$ & $149^{\circ} 51^{\prime} 18.00^{\prime \prime}$ \\
& MOR-168 & $17^{\circ} 29^{\prime} 21.91^{\prime \prime}$ & $149^{\circ} 51^{\prime} 05.26^{\prime \prime}$ \\
Phormidium sp.1 & MOR-170 & $17^{\circ} 28^{\prime} 58.87^{\prime \prime}$ & $149^{\circ} 50^{\prime} 06.47^{\prime \prime}$ \\
& MOR-090 & $17^{\circ} 29^{\prime} 23.00^{\prime \prime}$ & $149^{\circ} 53^{\prime} 36.40^{\prime \prime}$ \\
& MOR-025 & $17^{\circ} 35^{\prime} 30.50^{\prime \prime}$ & $149^{\circ} 51^{\prime} 18.00^{\prime \prime}$ \\
Plurispecific mats ${ }^{\prime}$ & MOR-064 & $17^{\circ} 32^{\prime} 24.24^{\prime \prime}$ & $149^{\circ} 54^{\prime} 16.05^{\prime \prime}$ \\
& MOR-065 & $17^{\circ} 31^{\prime} 43.11^{\prime \prime}$ & $149^{\circ} 54^{\prime} 48.52^{\prime \prime}$ \\
& MOR-169 & $17^{\circ} 28^{\prime} 58.91^{\prime \prime}$ & $149^{\circ} 50^{\prime} 10.32^{\prime \prime}$ \\
& MOR-208 & $17^{\circ} 28^{\prime} 47.63^{\prime \prime}$ & $149^{\prime} 48^{\prime} 27.78^{\prime \prime}$ \\
\hline
\end{tabular}

${ }^{1}$ The plurispecific mats were mainly composed of three major species-Anabaena sp.1, Anabaena sp.2 and Hydrocoleum majus-B. 

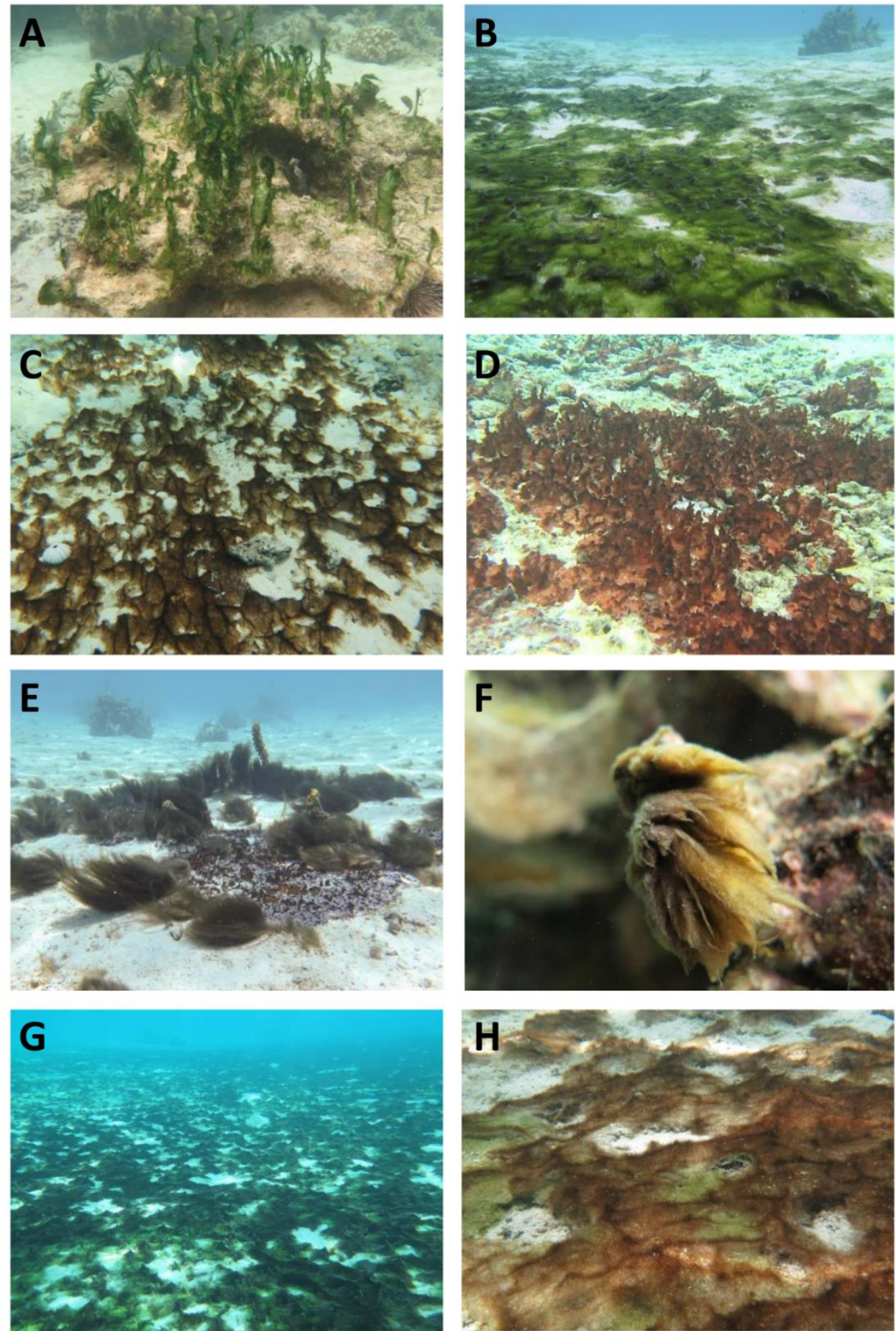

Figure 2. In situ photographs of benthic cyanobacteria mats sampled during the study. (A) Anabaena sp.1; (B) Anabaena sp.2; (C) Hydrocoleum majus-B; (D) Leptolyngbya sp.2; (E) Lyngbya majuscula; (F) Phormidium sp.1; (G-H) Plurispecific mats frequently occurring in channels of Moorea lagoon and composed of three major species-Anabaena sp.1, Anabaena sp.2 and H. majus-B.

Anabaena sp.1 forms blooms that are apparently becoming increasingly frequent in coral reefs of many tropical and sub-tropical areas worldwide, such as in islands of Moorea (blooms reported in previous studies as A. torulosa) [22,24,25,27], Tahiti, Mayotte and La Réunion [22], where they periodically cover entire reefs. L. majuscula has a long history of observations in different parts of the world, including massive blooms as well as reports of toxicity causing skin irritations, such as 
in Australia and Mayotte Island [10,40]. H. majus is the largest species of the genus that responds to eutrophication by building extensive mats [41].

\subsection{Chemical Profiles of Benthic Cyanobacterial Blooms}

The chemical profiles of the methanol-dichloromethane extracts from the 15 cyanobacterial bloom samples collected in the lagoon of Moorea Island displayed an interesting chemodiversity (Figure 3). The chemical fingerprints obtained for all samples of the same species were mostly comparable and appeared characteristic for the respective species. This was particularly obvious for Anabaena sp.1 and L. majuscula.
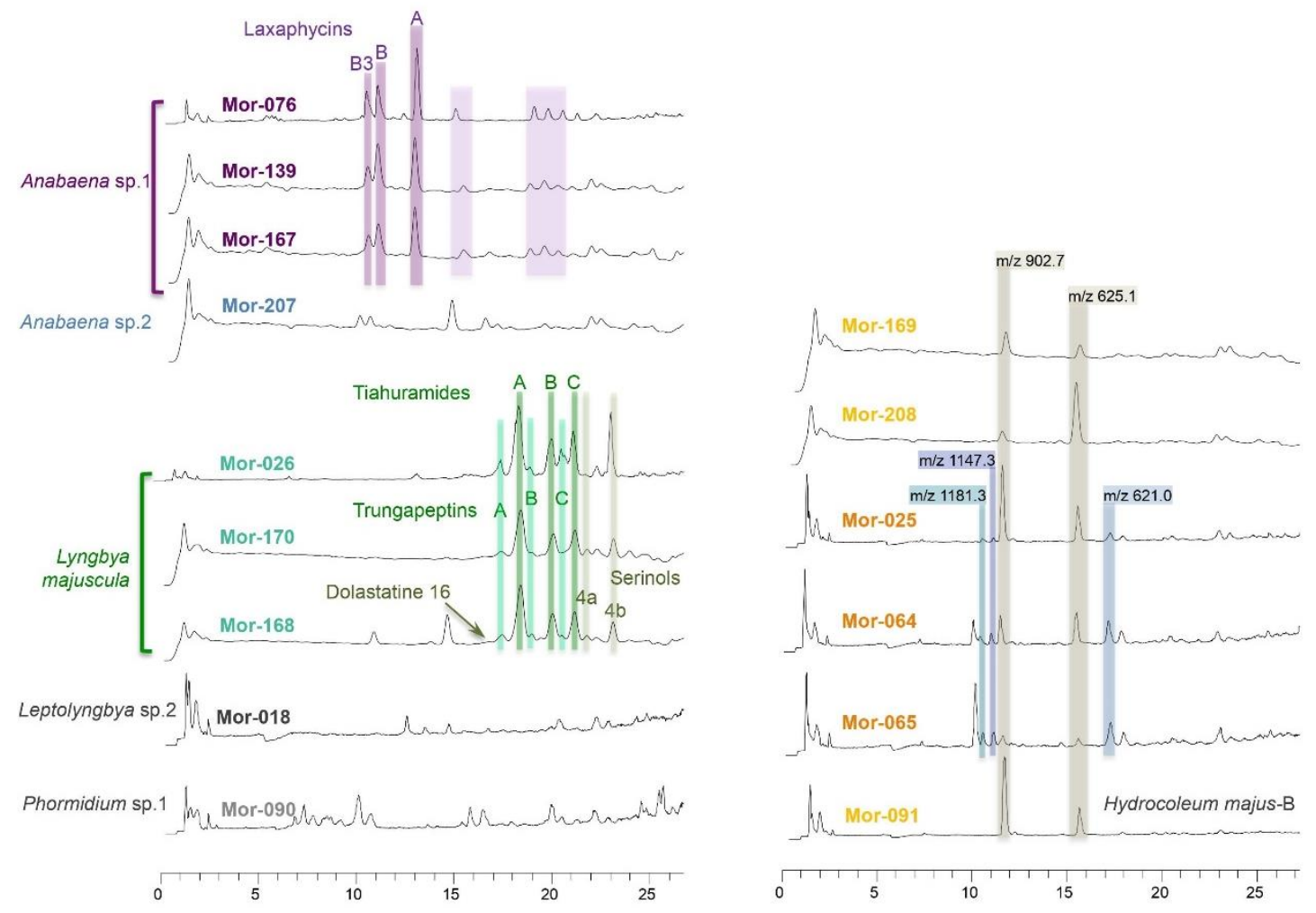

Figure 3. Liquid chromatography-mass spectrometry (LC-MS) chromatographic profiles (total ion current (TIC), electrospray ionization positive mode (ESI +), chromatographic conditions listed in the experimental part) of methanol-dichloromethane extracts from the 15 benthic cyanobacterial blooms collected in the lagoon of Moorea Island.

\subsubsection{Anabaena sp.1 Blooms}

The three blooms of Anabaena sp.1 (MOR-076, MOR-139 and MOR-167) showed identical chemical profiles dominated by three major cyclic lipopeptides of the laxaphycin family, among other unidentified compounds (Figure 3). Laxaphycins A, B and B3 detected in this study (Figure 4) were consistently found in A. torulosa samples from Moorea Island [24,25,27]. In contrast, cyclic and acyclic structural analogs of laxaphycins A, B and B3 from A. torulosa blooms collected in Moorea Island, which have been recently described $[25,27]$, were not detected in the samples analyzed in the present study. However, the production of these newly described congeners appeared atypical and could not be explained by any biotic and abiotic factors [25,27]. Structural variants of laxaphycins A have been described from cyanobacteria of diverse origins, Anabaena laxa or A. torulosa [24,27,42], Hormothamnion enteromorphoides [43], Lyngbya confervoides [44], Trichormus sp. [45], cf. Oscillatoria sp. [46] and six analogs of laxaphycin B have been found in A. laxa or A. torulosa [24,25,42], L. confervoides [44], Trichormus sp. [45], cf. Oscillatoria sp. [46] and a Lyngbya sp. strain [47]. Horizontal gene transfer between cyanobacteria 
has been invoked as an explanation for the presence of all these closely related compounds in diverse species [48].

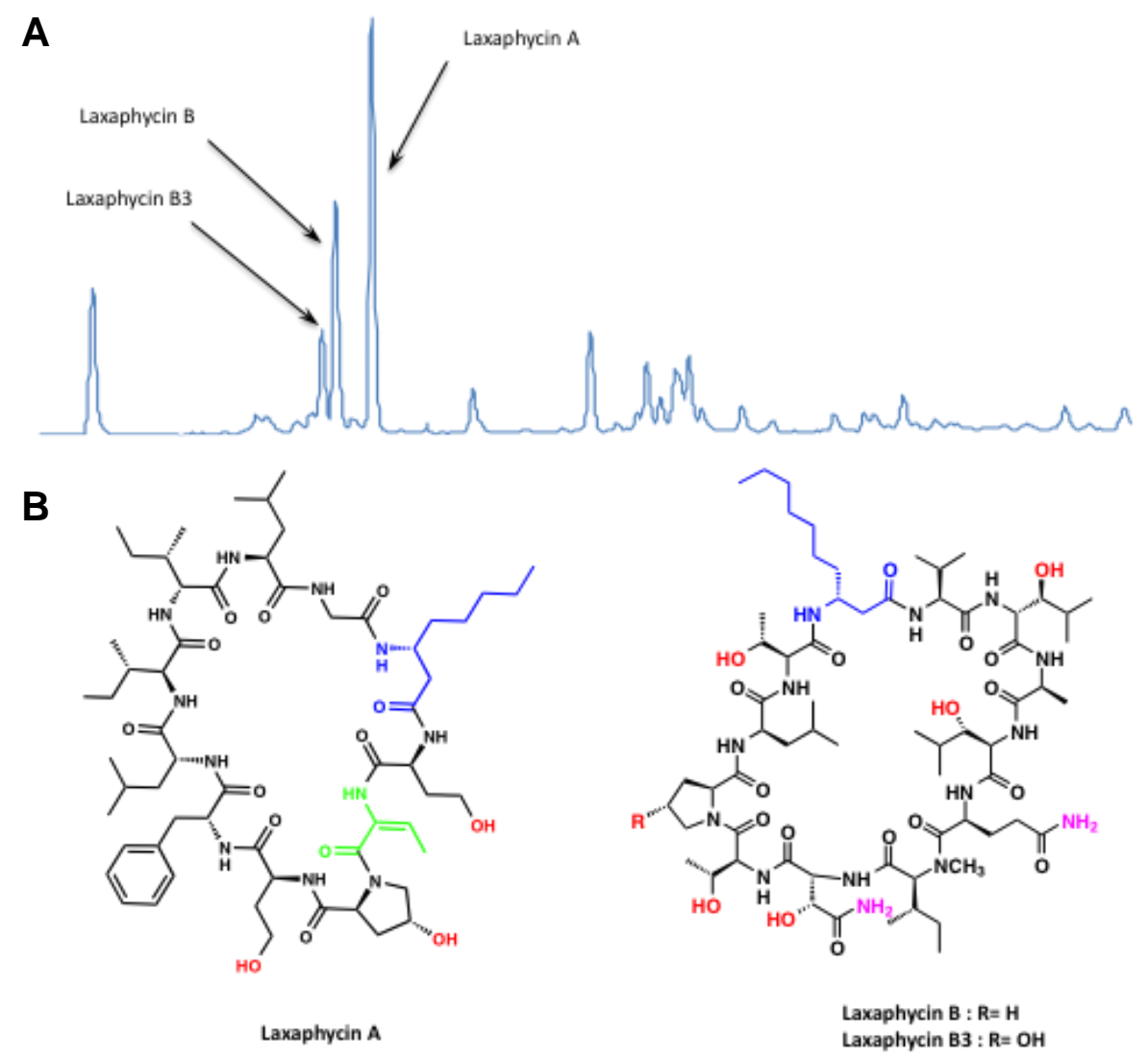

Figure 4. (A) LC-MS chromatographic profile (TIC, ESI+, chromatographic conditions listed in the experimental part) of a methanol-dichloromethane extract from Anabaena sp.1. (B) Structures of major lipopeptides.

\subsubsection{Lyngbya Majuscula Blooms}

The three blooms of L. majuscula (MOR-026, MOR-168, MOR-170) showed chemical profiles dominated by three cyclic lipopeptides of the tiahuramide family (Figure 3). Tiahuramides A, B and C (Figure 5) are typical of L. majuscula from Moorea Island [26]. Amongst the tiahuramides, the presence of trungapeptins (differing by an N-Me-Ile instead of an Ile residue) was also suspected, based on the pattern of fragmentation in LC-MS/MS (Supplementary Material S1). Tiahuramides are depsipeptides of the kulolide superfamily consisting of seven amino acids including a non-proteinogenic residue in forms such as alkane (Mhoaa in tiahuramide C), alkene (Mhoea in tiahuramide B) or alkyne (Mhoya in tiahuramide A). The kulolide superfamily includes cyclic penta-, hexa- or hepta-depsipeptides containing two ester linkages and a methyl or dimethylhydroxyoctynoic acid residue such as yanucamides [49], antanapeptins [33], pitipeptolides [50,51], trungapeptins [36], hantupeptins [52,53], lagunamides $[54,55]$ and viquieamides [56], which have been found in various cyanobacteria but also in the cephalaspidean mollusk Philinopsis speciosa [57]. The structural similarities within this large series of cyclic depsipeptides, as well as their diverse origin in the marine area, suggest the existence of a kulolide superfamily which may have an ancient evolutionary origin within the cyanobacteria [56]. 


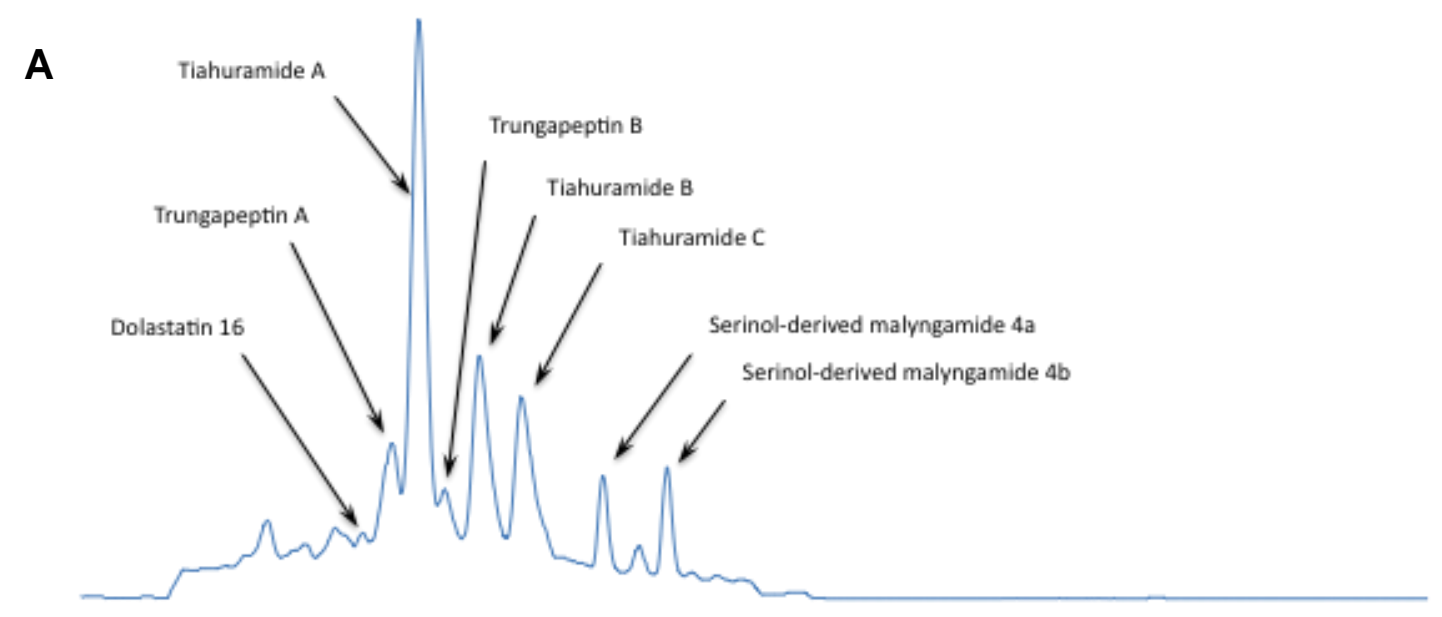

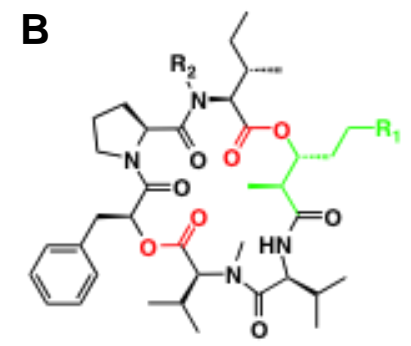

R1 $=(2 S, 3 R)-$ Mhoya $=$

$R 1=(2 S, 3 R)-$ Mhoea $=\$$

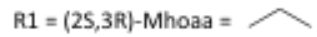

Tiahuramides A, B, C : $\mathbf{R}_{1}=$ Mhoya, Mhoea, Mhoaa; $\mathbf{R}_{2}=$ Me

Trungapeptins A, B, C : $\mathbf{R}_{1}=$ Mhoya, Mhoea, Mhoaa; $\mathbf{R}_{2}=\mathbf{H}$

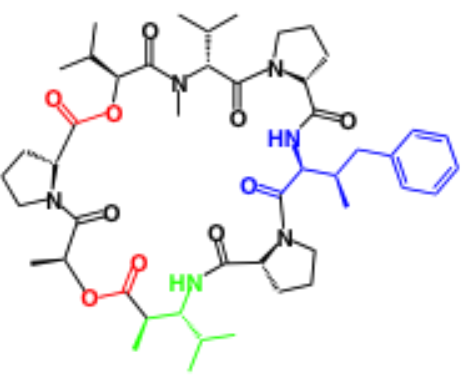

Dolastatin 16<smiles>CCCCCCC=CCCC(=O)NC(COC)COC(C)=O</smiles>

Serinol-derived malyngamide $4 a$<smiles>CCCCCC(C)OC</smiles>

Serinol-derived malyngamide $4 \mathrm{~b}$

Figure 5. (A) LC-MS chromatographic profile (TIC, ESI+, chromatographic conditions listed in the experimental part) of a methanol-dichloromethane extract from Lyngbya majuscula. (B) Structures of major secondary metabolites.

In addition to these cyclic lipopeptides, the chemical profile of L. majuscula also showed two major compounds identified as serinol-derived malyngamides $4 \mathrm{a}$ and $4 \mathrm{~b}$ (Figures 3 and 5 ) according to LC-MS/MS and RMN data (Supplementary Material S1). Serinol-derived malyngamides $4 \mathrm{a}$ and $4 \mathrm{~b}$ were found in all L. majuscula samples analyzed, that is, not only in the present analytic series but also in previous series [26]; therefore they appear characteristic of the chemical profile of L. majuscula from Moorea Island. To date, more than 30 malyngamide-type metabolites have been reported in the literature to be produced by L. majuscula, without specifying whether these molecules were isolated together with peptides of the kulolide superfamily. To the best of our knowledge, only Wan and Erickson [35] had previously described serinol-derived malyngamides from an Australian cyanobacterium.

In contrast, the presence of dolastatin 16 in MOR-168 (Figures 3 and 5), based on LC-MS/MS and RMN data (Supplementary Material S1), was unique within all samples examined from Moorea Island. This cyclic didepsilipopeptide has been first isolated from the sea hare Dolabella auricularia [34], then from an L. majuscula collected in Madagascar [33]. Jointly with dolastatin 16, Nogle and Gerwick [33] isolated antanapeptins A-D, peptides structurally close to tiahuramides, from the same blue-green specimen and Montaser et al. $[51,58]$ isolated pitiprolamide, a proline-rich dolastatin 16 analog, together with pitipeptolides from a Lyngbya majuscula from Guam.

The complexity of the chemical profiles of L. majuscula is consistent with the abundant literature on the variety of compounds isolated from this organism [10,12]. To date, more than 260 compounds have been identified in the genus Lyngbya, including 196 compounds allocated to the species L. majuscula alone [59]. Several hypotheses may explain this remarkable chemodiversity, including (i) the influence 
of environmental factors on biosynthetic pathways or (ii) a misidentification of individuals due to the genetic diversity of variants (cryptic species) within the nominal species traditionally identified by morphology alone. The potential cryptic speciation within $L$. majuscula requires molecular approaches at the population level that have not been addressed in the present study, so does the derivation of metabolomic properties along with the phylogenetic background of this cyanobacterium. The misidentification hypothesis is supported by the observation of similar compounds within distant groups or their absence within individuals from the same genus. Moreover, it is important to note that symbiotic and epiphytic organisms are often found associated with L. majuscula so that a possible overestimation of the chemical diversity of this cyanobacteria cannot be completely ruled out. This hypothesis is sustained by genomic and phylogenetic studies. Jones et al. [60] concluded in their study on an L. majuscula strain that only 126 genes, reportedly dedicated to secondary metabolites synthesis, transportation and catabolism, could not explain such chemodiversity. A contrario, Engene et al. [61,62] have highlighted the polyphylogeny of individuals within the Lyngbya genus from Curacao Island based on $16 \mathrm{~S}$ rDNA molecular analysis.

In samples collected during the present study, peptides of the kulolide superfamily have been observed in L. majuscula metabolome in the form of a complex mixture including tiahuramides and trungapeptins, in association with serinol-derived malyngamides. This association of diverse nitrogen compounds within L. majuscula has often been observed [33,63]. Nevertheless, the overall pattern of the chemical profile of L. majuscula differed little across sampling sites, that is, in northern vs. southern locations, characterized by contrasting ocean swell and anthropogenic activities conditions.

\subsubsection{Other Blooms}

The bloom sample predominated by $H$. majus-B (MOR-091) revealed a rather simple chemical pattern showing two major peaks $(\mathrm{rt}=11.04, \mathrm{~m} / \mathrm{z}=902.7,596.3,452.2$; and $\mathrm{rt}=14.58, \mathrm{~m} / \mathrm{z}=625.1,560.2$, 425.2) (Figure 3). Unfortunately, the UV absorption data for these two unknown compounds could not be recorded and attempts to isolate and purify them failed due to their rapid degradation during the extraction and analysis process. The chemical profile of $H$. majus-B, apparently less complex than those of Anabaena sp.1 and L. majuscula, was actually quite difficult to interpret since the major compounds were displayed in a multiple mass cluster and biodegraded rapidly. Overall, very few secondary metabolites have been reported from this genus [63], including the neurotoxin homoanatoxin-a (HANTX), previously characterized in a Hydrocoleum lyngbyaceum bloom and possibly linked to giant clam poisoning incidents in New Caledonia [15], and the toxins lyngbyastatin-1 and -3 as well as an amino acid related to tumonoic acids, isolated from a cyanobacterium possibly morphologically close to Hydrocoleum cantharidosmum [64].

The second unidentified compound detected in H. majus-B bloom was also present in various proportions in all the plurispecific mats (MOR-025, MOR-064, MOR-065, MOR-169 and MOR-208) composed primarily of Anabaena sp.1, Anabaena sp.2 and H. majus-B, whereas the first unidentified compound was only detected in three of them (MOR-025, MOR-064, MOR-065) (Figure 3). Additionally, the chemical profiles of three of the plurispecific mats (MOR-025, MOR-064 and MOR-065) also showed the presence of the three peaks observed in the chromatogram of Anabaena sp.2 (MOR-207, $\mathrm{rt}=10.07 \mathrm{~min} ; \mathrm{m} / \mathrm{z} 1181.3$ and $610.5, \mathrm{rt}=10.63 \mathrm{~min} ; \mathrm{m} / \mathrm{z} 1147.3$ and 593.6 and $\mathrm{rt}=16.57 \mathrm{~min} ; \mathrm{m} / \mathrm{z} 621.0$ ) (Figure 3). In contrast, no laxaphycins were detected in these plurispecific mats despite the presence of Anabaena sp.1. Thus, the plurispecific mats show more or less similar chemical profiles although the proportions between compounds differ. Even though the relative abundance of cyanobacterial species within each mat was not evaluated, several hypotheses could explain the distinct proportions of metabolites-(i) the compound ratio is relative to the mass ratio of cyanobacteria and differs in each sample or (ii) the synthesis of these secondary metabolites is influenced by (a) differing environmental conditions prevailing across sampling sites or $(b)$ interactions between cyanobacteria within a plurispecific mat. 
Finally, Phormidium sp.1 (MOR-090) and Leptolyngbya sp.2 (MOR-018) showed different and characteristic chemical profiles, which displayed secondary metabolites that cannot be confounded with any of the compounds found in the other species (Figure 3).

\subsection{Toxicity of Benthic Cyanobacterial Blooms}

Only four lipophilic fractions $\left(\mathrm{CH}_{2} \mathrm{Cl}_{2}\right)$, concentrated in lipids and lipopeptides, from Anabaena sp.1 (MOR-139 and MOR-167) and plurispecific mats (MOR-025 and MOR-065) induced a lethality of A. salina nauplii between $20 \%$ and $40 \%$ (Figure 6). These results are consistent with previous assays (Bornancin 2019, personal communication) showing that tiahuramides and laxaphycin A were not toxic on brine-shrimp nauplii $\left(0 \%\right.$ lethality at $\left.200 \mu \mathrm{g} \mathrm{mL} \mathrm{m}^{-1}\right)$ and laxaphycins B-type were weakly active (93\% to $95 \%$ lethality at $200 \mu \mathrm{g} \mathrm{mL} \mathrm{L}^{-1}$ and $25 \%$ to $30 \%$ lethality at $20 \mu \mathrm{g} \mathrm{mL} \mathrm{m}^{-1}$ for laxaphycins B and B3, respectively). However, laxaphycins B and B3 were likely responsible for only a part of the toxicity of cyanobacteria since the toxic activity on nauplii was found to vary between Anabaena sp.1 samples while their lipopeptide signature was similar.

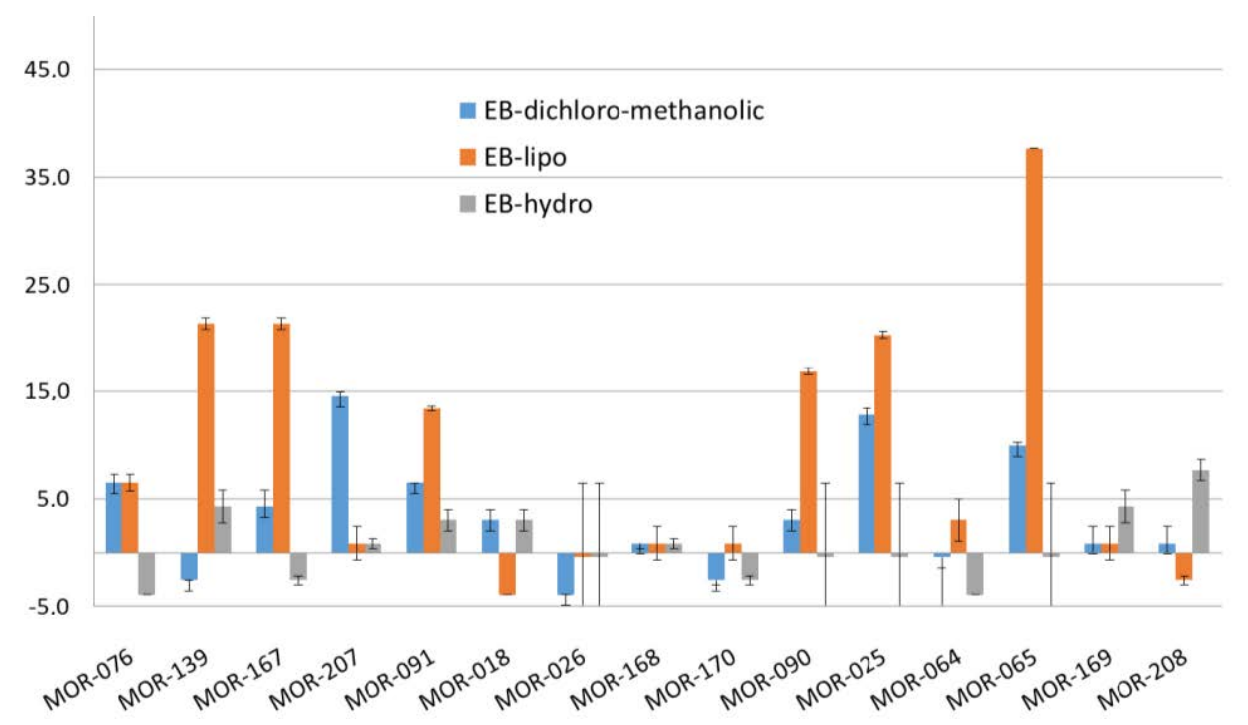

Figure 6. Toxicity of the 15 benthic cyanobacterial bloom samples on Artemia salina nauplii, expressed in percentage of lethality. The methanol-dichloromethane desalted extracts (EB-dichloro-methanolic), lipophilic fractions (EB-lipo) and hydrophilic fractions (EB-hydro) were tested at a concentration of $100 \mu \mathrm{g} \mathrm{mL}^{-1}$ (1\% DMSO in seawater). Data represent the means \pm standard errors (SE); $n=3$ in all cases.

Regarding CBA-N2a results, the lipophilic fractions from the three Anabaena sp.1 monospecific blooms (MOR-076, MOR-139 and MOR-167) revealed toxicity potentially typical of the presence of toxins acting as VGSCs activators (e.g., CTX-like toxins)—indeed, weak cytotoxic effects were observed in $\mathrm{OV}^{+}$condition, whereas no cytotoxicity was detected in $\mathrm{OV}^{-}$condition (Figure 7). $\mathrm{EC}_{50}$ values of 5.9, 3.8 and $4.5 \mathrm{ng}$ dried extract $\mu \mathrm{L}^{-1}$, corresponding to toxin contents of 7.8, 2.0 and $21.8 \mathrm{ng}$ P-CTX3C equiv. $\mathrm{g}^{-1}$ freeze-dried cyanobacteria, were estimated for lipophilic fractions of MOR-076, MOR-139 and MOR-167, respectively. Interestingly, lipophilic fractions from an Anabaena sp. bloom from Lifou Island (New Caledonia) [16] and two Anabaena sp.1 blooms from Tahiti and Mangareva Islands (French Polynesia) (M. Roué, unpublished data) previously showed a similar activity using CBA-N2a. 


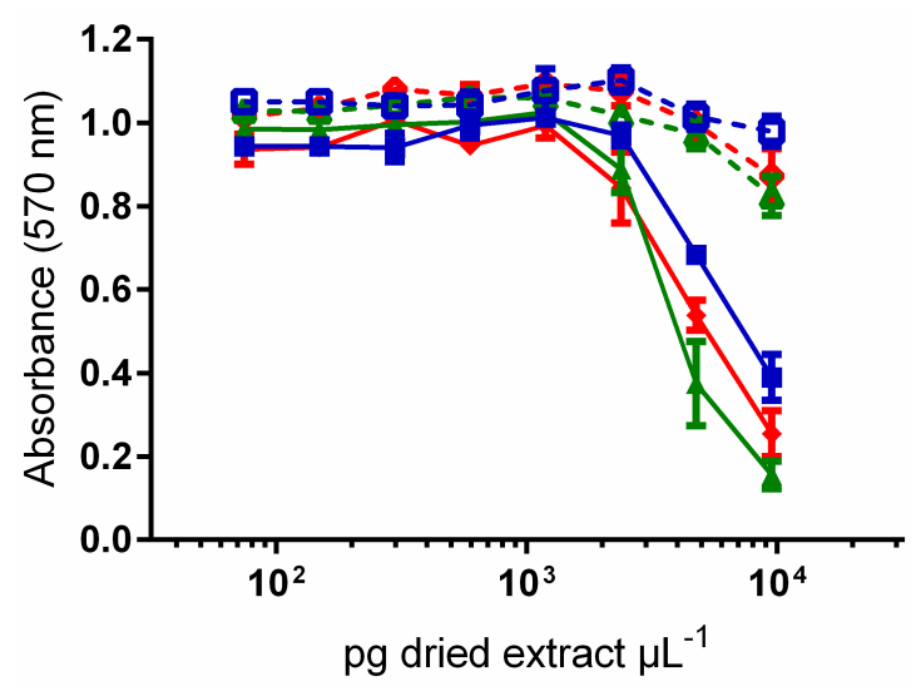

Figure 7. Dose-response curves for neuroblastoma (N2a) cells exposed, in the absence (OV ${ }^{-}$condition, open symbols) and presence ( $\mathrm{OV}^{+}$condition, solid symbols) of ouabain and veratridine, to increasing

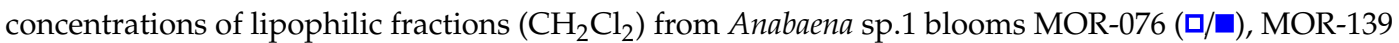
$(\Delta / \Delta)$ and MOR-167 $(\circ / \bullet)$ collected in the lagoon of Moorea Island. Data represent the means \pm SE of values obtained from three independent neuroblastoma cell-based assays (CBA-N2a), each point run in triplicate.

However, further LC-MS analyses failed to detect the presence of any known VGSC activators, including CTXs (data not shown). Therefore, the weak toxicity detected on neuroblastoma cells could be consistent with the cytotoxic activities against cancerous cells exhibited by laxaphycins A and B [24,65], two compounds detected in Anabaena sp.1 samples. In any case, given the very low level of toxicity detected in Anabaena sp.1 blooms tested in the present study using CBA-N2a, health hazards associated with them appear negligible for now, especially as the bioavailability of potentially toxic compounds during direct ingestion, contact or via a trophic translocation scenario has still to be demonstrated.

None of the other cyanobacterial fractions, both lipophilic and hydrophilic, were found toxic on neuroblastoma cells in the laboratory conditions used for looking at the presence of VGSC toxin activators.

Tiahuramides B and C detected in the three blooms of L. majuscula were previously shown to exhibit moderate toxicity in SH-SY5Y human neuroblastoma cells, unlike tiahuramide A which was non-toxic [26]. In the present study, only the crude lipophilic fractions were tested on murine N2a cells and tiahuramides $\mathrm{B}$ and $\mathrm{C}$ were not the major compounds (tiahuramide A was), therefore, an activity could maybe be observed if pure compounds had been tested. Similarly, L. majuscula is also known to produce several other neurotoxic lipopeptides-(i) antillatoxins exhibit neurotoxicity that activates VGSCs and have potent cytotoxicity toward murine N2a cells, (ii) jamaicamides are VGSC-blocking substances and (iii) kalkitoxins are toxic to brine-shrimp and potently block VGSCs in murine N2a cells (for a review, see Reference [4]). The absence of these neurotoxic lipopeptides in the chemical profiles of $L$. majuscula blooms from Moorea Island is consistent with the lack of toxicity of L. majuscula samples on N2a cells and Artemia salina nauplii. Finally, L. majuscula is a known producer of dermatotoxins (e.g., aplysiatoxins) responsible for human skin diseases through external contact [11] and is suspected of contributing to chelonitoxism, a human poisoning condition caused by the ingestion of the meat of marine turtles that have bioaccumulated lyngbyatoxin A [66,67]. Thus, it could be worth conducting further bioassays using different cell lines, in order to assess the potential health hazards represented by blooms of this cyanobacterium species. In any case, different environmental factors or genetic differences may account for the absence of toxicity in L. majuscula bloom samples from Moorea Island. 
Finally, a previous study has reported the presence of CTX-like compounds, together with paralytic shellfish toxins (PSTs) and neurotoxins, in marine benthic cyanobacteria of the genus Hydrocoleum (mainly H. lyngbyaceum) sampled from New Caledonia and their possible implication in human poisonings [13]. However, $H$. majus-B was apparently not observed among the implicated species and chemical profiles, as well as toxicity, are likely to vary between species, which is consistent with the non-toxicity of H. majus-B samples from Moorea Island.

\section{Conclusions}

Fifteen proliferations of benthic cyanobacteria collected from the lagoon of Moorea Island over a six months survey during the warm season of 2014-2015 were examined for their chemodiversity and toxic potential. Three major bloom-forming species were identified in twelve of these blooms, namely Anabaena sp.1, Hydrocoleum majus-B and Lyngbya majuscula. Chemical profiles of organic extracts, acquired using HPLC-UV-MS, proved to be characteristic for each species. Lipopeptides appear to possess a chemotaxonomic value for both L. majuscula and Anabaena sp.1 species. Indeed, tiahuramides and laxaphycins can be considered as chemotaxonomic markers for L. majuscula and Anabaena sp.1, respectively. Concerning H. majus-B, the two unidentified compounds, if characterized, could also be used as chemotaxonomic markers for the species. Regarding toxicological data, if Anabaena sp.1 samples revealed low toxicity on brine-shrimp nauplii and murine neuroblastoma cells, L. majuscula, H. majus-B and plurispecific mats showed no activity using CBA-N2a assay or weak toxicity on Artemia salina. Health hazards associated with benthic cyanobacterial proliferations in Moorea Island thus appear negligible for now. However, as described in the literature, L. majuscula [11,40] and Hydrocoleum spp. [13-16] in marine environments, as well as Anabaena spp. [3] in freshwater environments, produce toxins that can cause potential health issues. These previous findings thus encourage the implementation of an ad hoc surveillance of the toxicity of these three bloom-forming species in Moorea Island and more globally in French Polynesia, using, for instance, a non-targeted metabolomic approach $[68,69]$ and/or other cytotoxicity-based functional assays [70].

Supplementary Materials: The following are available online at http://www.mdpi.com/2077-1312/8/6/406/s1, Supplementary material S1: Compounds isolated from Lyngbya majuscula-(A) Isolation procedure, (B) Structural elucidation procedure, (C) Identification of compounds (tiahuramides and analogs, serinol-derived malyngamides $4 \mathrm{a}$ and $4 \mathrm{~b}$, dolastatin 16); Table S1: List of benthic cyanobacterial bloom samples sequenced for DNA-assisted species identification, with indications of the marker sequenced, collection information, Genbank accession number and DNA sequence length.

Author Contributions: Conceptualization, I.B., M.Z., B.B. and M.R.; Data curation, I.B., B.B. and M.R.; Formal analysis, I.B., L.B., K.D., M.Z., B.B. and M.R.; Funding acquisition, M.Z. and M.R.; Methodology, I.B., L.B., K.D., M.Z., B.B. and M.R.; Project administration, M.Z.; Supervision, M.R.; Validation, I.B., M.C., B.B. and M.R.; Writing-original draft, I.B. and M.R.; Writing—review \& editing, I.B., M.C., M.Z., B.B. and M.R. All authors have read and agreed to the published version of the manuscript.

Funding: The present work was supported by funds from France in the framework of the "CYANODIV" (Laboratoire d'Excellence CORAIL 2014) and "CYANOTOX" (Fonds Pacifique, no. AFD CPF 144001 N of 22 December 2016) research programs.

Acknowledgments: The authors wish to thank the technicians of CRIOBE (Moorea) and Mathieu Grellier for their help and support during field expeditions. The authors also greatly acknowledge Jérôme Viallon and Hélène Taiana Darius from the Institut Louis Malardé (Tahiti) for the CBA-N2a analyses. Chromatographic, spectroscopic and structural analyses were performed using the facilities of the Biodiversité et Biotechnologies Marines platform at the University of Perpignan (Bio2Mar, http://bio2mar.obs-banyuls.fr/fr/index.html). Finally, authors thank the two anonymous reviewers whose comments greatly helped improve the manuscript.

Conflicts of Interest: The authors declare no conflict of interest. The funders had no role in the design of the study; in the collection, analyses or interpretation of data; in the writing of the manuscript or in the decision to publish the results. 


\section{References}

1. Brocks, J.J.; Logan, G.A.; Buick, R.; Summons, R.E. Archean molecular fossils and the early rise of eukaryotes. Science 1999, 285, 1033. [CrossRef] [PubMed]

2. Mishra, A.K.; Tiwari, D.N.; Rai, A.N. Cyanobacteria: From Basic Science to Applications; Academic Press: Cambridge, MA, USA, 2019.

3. Bernard, C.; Ballot, A.; Thomazeau, S.; Maloufi, S.; Furey, A.; Mankiewicz-Boczek, J.; Pawlik-Skowrońska, B.; Capelli, C.; Salmaso, N. Appendix 2: Cyanobacteria associated with the production of cyanotoxins. In Handbook of Cyanobacterial Monitoring and Cyanotoxin Analysis; Meriluoto, J., Spoof, L., Codd, G.A., Eds.; John Wiley \& Sons: Hoboken, NJ, USA, 2017; pp. 501-525.

4. Du, X.; Liu, H.; Yuan, L.; Wang, Y.; Ma, Y.; Wang, R.; Chen, X.; Losiewicz, D.M.; Guo, H.; Zhang, H. The diversity of cyanobacterial toxins on structural characterization, distribution and identification: A systematic review. Toxins 2019, 11, 530. [CrossRef] [PubMed]

5. Burja, A.M.; Banaigs, B.; Abou-Mansour, E.; Grant Burgess, J.; Wright, P.C. Marine cyanobacteria-A prolific source of natural products. Tetrahedron 2001, 57, 9347-9377. [CrossRef]

6. Tan, L.T. Bioactive natural products from marine cyanobacteria for drug discovery. Phytochemistry 2007, 68, 954-979. [CrossRef] [PubMed]

7. Salvador-Reyes, L.A.; Luesch, H. Biological targets and mechanisms of action of natural products from marine cyanobacteria. Nat. Prod. Rep. 2015, 32, 478-503. [CrossRef] [PubMed]

8. Mi, Y.; Zhang, J.; He, S.; Yan, X. New peptides isolated from marine cyanobacteria, an overview over the past decade. Mar. Drugs 2017, 15, 132. [CrossRef]

9. Roué, M.; Gugger, M.; Golubic, S.; Amzil, Z.; Aráoz, R.; Turquet, J.; Chinain, M.; Laurent, D. Marine cyanotoxins potentially harmful to human health. In Outstanding Marine Molecules; La Barre, S., Kornprobst, J.-M., Eds.; Wiley-VCH Verlag GmbH \& Co. KGaA: Weinheim, Germany, 2014; pp. 3-22.

10. Osborne, N.J.T.; Webb, P.M.; Shaw, G.R. The toxins of Lyngbya majuscula and their human and ecological health effects. Environ. Int. 2001, 27, 381-392. [CrossRef]

11. Osborne, N.; Seawright, A.; Shaw, G. Dermal toxicology of Lyngbya majuscula from Moreton Bay, Queensland, Australia. Harmful Algae 2008, 7, 584-589. [CrossRef]

12. Taylor, M.S.; Stahl-Timmins, W.; Redshaw, C.H.; Osborne, N.J. Toxic alkaloids in Lyngbya majuscula and related tropical marine cyanobacteria. Harmful Algae 2014, 31, 1-8. [CrossRef]

13. Laurent, D.; Kerbrat, A.-S.; Darius, H.T.; Girard, E.; Golubic, S.; Benoit, E.; Sauviat, M.-P.; Chinain, M.; Molgo, J.; Pauillac, S. Are cyanobacteria involved in Ciguatera Fish Poisoning-like outbreaks in New Caledonia? Harmful Algae 2008, 7, 827-838. [CrossRef]

14. Golubic, S.; Abed, R.M.M.; Palińska, K.; Pauillac, S.; Chinain, M.; Laurent, D. Marine toxic cyanobacteria: Diversity, environmental responses and hazards. Toxicon 2010, 56, 836-841. [CrossRef] [PubMed]

15. Méjean, A.; Peyraud-Thomas, C.; Kerbrat, A.S.; Golubic, S.; Pauillac, S.; Chinain, M.; Laurent, D. First identification of the neurotoxin homoanatoxin-a from mats of Hydrocoleum lyngbyaceum (marine cyanobacterium) possibly linked to giant clam poisoning in New Caledonia. Toxicon 2010, 56, 829-835. [CrossRef] [PubMed]

16. Laurent, D.; Kerbrat, A.S.; Darius, H.T.; Rossi, F.; Yeeting, B.; Haddad, M.; Golubic, S.; Pauillac, S.; Chinain, M. Ciguatera Shellfish Poisoning (CSP): A new ecotoxicological phenomenon from cyanobacteria to humans via giant clams. In Food Chains: New Research; Jensen, M.A., Muller, D.W., Eds.; Nova Science Publishers: Hauppauge, NY, USA, 2012; pp. 1-44.

17. Kuffner, I.B.; Walters, L.J.; Becerro, M.A.; Paul, V.J.; Ritson-Williams, R.l.; Beach, K.S. Inhibition of coral recruitment by macroalgae and cyanobacteria. Mar. Ecol. Prog. Ser. 2006, 323, 107-117. [CrossRef]

18. Kramarsky-Winter, E.; Arotsker, L.; Rasoulouniriana, D.; Siboni, N.; Loya, Y.; Kushmaro, A. The possible role of cyanobacterial filaments in coral black band disease pathology. Microb. Ecol. 2014, 67, 177-185. [CrossRef] [PubMed]

19. Morrow, K.M.; Ritson-Williams, R.; Ross, C.; Liles, M.R.; Paul, V.J. Macroalgal extracts induce bacterial assemblage shifts and sublethal tissue stress in Caribbean corals. PLoS ONE 2012, 7, e44859. [CrossRef] [PubMed]

20. O'Neil, J.M.; Davis, T.W.; Burford, M.A.; Gobler, C.J. The rise of harmful cyanobacteria blooms: The potential roles of eutrophication and climate change. Harmful Algae 2012, 14, 313-334. [CrossRef] 
21. Paerl, H.W.; Paul, V.J. Climate change: Links to global expansion of harmful cyanobacteria. Water Res. 2012, 46, 1349-1363. [CrossRef]

22. Zubia, M.; Vieira, C.; Palinska, K.; Roué, M.; Gaertner, J.-C.; Zloch, I.; Grellier, M.; Golubic, S. Benthic cyanobacteria on coral reefs of Moorea Island (French Polynesia): Diversity response to habitat quality. Hydrobiologia 2019, 843, 61-78. [CrossRef]

23. Bonnard, I.; Rolland, M.; Francisco, C.; Banaigs, B. Total structure and biological properties of laxaphycins A and B, cyclic lipopeptides from the marine cyanobacterium Lyngbya majuscula. Lett. Pept. Sci. 1997, 4, 289-292. [CrossRef]

24. Bonnard, I.; Rolland, M.; Salmon, J.-M.; Debiton, E.; Barthomeuf, C.; Banaigs, B. Total structure and inhibition of tumor cell proliferation of laxaphycins. J. Med. Chem. 2007, 50, 1266-1279. [CrossRef]

25. Bornancin, L.; Boyaud, F.; Mahiout, Z.; Bonnard, I.; Mills, S.C.; Banaigs, B.; Inguimbert, N. Isolation and synthesis of laxaphycin B-type peptides: A case study and clues to their biosynthesis. Mar. Drugs 2015, 13, 7285-7300. [CrossRef] [PubMed]

26. Levert, A.; Alvariño, R.; Bornancin, L.; Abou Mansour, E.; Burja, A.M.; Genevière, A.-M.; Bonnard, I.; Alonso, E.; Botana, L.; Banaigs, B. Structures and activities of tiahuramides A-C, cyclic depsipeptides from a Tahitian collection of the marine cyanobacterium Lyngbya majuscula. J. Nat. Prod. 2018, 81, 1301-1310. [CrossRef] [PubMed]

27. Bornancin, L.; Alonso, E.; Alvariño, R.; Inguimbert, N.; Bonnard, I.; Botana, L.M.; Banaigs, B. Structure and biological evaluation of new cyclic and acyclic laxaphycin-A type peptides. Bioorg. Med. Chem. 2019, 27, 1966-1980. [CrossRef] [PubMed]

28. Villeneuve, A.; Laurent, D.; Chinain, M.; Gugger, M.; Humbert, J.-F. Molecular characterization of the diversity and potential toxicity of cyanobacterial mats in two tropical lagoons in the South Pacific Ocean. J. Phycol. 2012, 48, 275-284. [CrossRef] [PubMed]

29. Manger, R.L.; Leja, L.S.; Lee, S.Y.; Hungerford, J.M.; Hokama, Y.; Dickey, R.W.; Granade, H.R.; Lewis, R.; Yasumoto, T.; Wekell, M.M. Detection of sodium channel toxins: Directed cytotoxicity assays of purified ciguatoxins, brevetoxins, saxitoxins, and seafood extracts. J. AOAC Int. 1995, 78, 521-527. [CrossRef] [PubMed]

30. Chinain, M.; Gatti, C.M.; Roué, M.; Darius, H.T. Ciguatera poisoning in French Polynesia: Insights into the novel trends of an ancient disease. New Microbes New Infect. 2019, 31, 100565. [CrossRef]

31. Skinner, M.P.; Brewer, T.D.; Johnstone, R.; Fleming, L.E.; Lewis, R.J. Ciguatera fish poisoning in the Pacific Islands (1998 to 2008). PLoS Negl. Trop. Dis. 2011, 5, e1416. [CrossRef]

32. Chinain, M.; Darius, H.T.; Gatti, C.M.; Roué, M. Biotoxines marines et sécurité sanitaire des ressources lagonaires en Polynésie française. In La Sécurité Alimentaire (Les Cahiers de Droit de la Santé Juridiques, Historiques et Prospectifs n²7); Mu Si Yan, L., Qi, J., De Raulin, A., Eds.; LEH Editions: Bordeaux, France, 2018; pp. 119-143.

33. Nogle, L.M.; Gerwick, W.H. Isolation of four new cyclic depsipeptides, antanapeptins A-D, and dolastatin 16 from a Madagascan collection of Lyngbya majuscula. J. Nat. Prod. 2002, 65, 21-24. [CrossRef]

34. Pettit, G.R.; Xu, J.-P.; Hogan, F.; Williams, M.D.; Doubek, D.L.; Schmidt, J.M.; Cerny, R.L.; Boyd, M.R. Isolation and structure of the human cancer cell growth inhibitory cyclodepsipeptide dolastatin 16. J. Nat. Prod. 1997, 60, 752-754. [CrossRef]

35. Wan, F.; Erickson, K.L. Serinol-derived malyngamides from an Australian cyanobacterium. J. Nat. Prod. 1999, 62, 1696-1699. [CrossRef]

36. Bunyajetpong, S.; Yoshida, W.Y.; Sitachitta, N.; Kaya, K. Trungapeptins A-C, cyclodepsipeptides from the marine cyanobacterium Lyngbya majuscula. J. Nat. Prod. 2006, 69, 1539-1542. [CrossRef] [PubMed]

37. Viallon, J.; Chinain, M.; Darius, T.H. Revisiting the neuroblastoma cell-based assay (CBA-N2a) for the improved detection of marine toxins active on voltage gated sodium channels (VGSCs). Toxins 2020, 12, 281. [CrossRef] [PubMed]

38. Meyer, B.N.; Ferrigni, N.R.; Putnam, J.E.; Jacobsen, L.B.; Nichols, D.E.; McLaughlin, J.L. Brine shrimp: A convenient general bioassay for active plant constituents. Planta Med. 1982, 45, 31-34. [CrossRef] [PubMed]

39. Rajabi, S.; Ramazani, A.; Hamidi, M.; Naji, T. Artemia salina as a model organism in toxicity assessment of nanoparticles. DARU J. Pharm. Sci. 2015, 23, 20. [CrossRef] [PubMed] 
40. Lernout, T.; Thiria, J.; Maltaverne, E.; Salim, M.; Turquet, J.; Lajoinie, G.; Solet, J.L.; Filleul, L. Alerte aux cyanobactéries sur la plage de N'Gouja, Mayotte, avril 2010. Bulletin de Veille Sanitaire de la Cellule de l'Institut de Veille Sanitaire en Régoin Océan Indien 2012, 9, 12-14.

41. Charpy, L.; Casareto, B.E.; Langlade, M.J.; Suzuki, Y. Cyanobacteria in coral reef ecosystems: A review. J. Mar. Biol. 2012, 2012, 1-9. [CrossRef]

42. Frankmölle, W.P.; Knübel, G.; Moore, R.E.; Patterson, G.M. Antifungal cyclic peptides from the terrestrial blue-green alga Anabaena laxa. II. Structures of laxaphycins A, B, D and E. J. Antibiot. 1992, 45, 1458-1466. [CrossRef]

43. Gerwick, W.H.; Jiang, Z.D.; Agarwal, S.K.; Farmer, B.T. Total structure of hormothamnin A, a toxic cyclic undecapeptide from the tropical marine cyanobacterium Hormothamnion enteromorphoides. Tetrahedron 1992, 48, 2313-2324. [CrossRef]

44. MacMillan, J.B.; Ernst-Russell, M.A.; de Ropp, J.S.; Molinski, T.F. Lobocyclamides A-C, lipopeptides from a cryptic cyanobacterial mat containing Lyngbya confervoides. J. Org. Chem. 2002, 67, 8210-8215. [CrossRef]

45. Luo, S.; Krunic, A.; Kang, H.-S.; Chen, W.-L.; Woodard, J.L.; Fuchs, J.R.; Swanson, S.M.; Orjala, J. Trichormamides A and B with antiproliferative activity from the cultured freshwater cyanobacterium Trichormus sp. UIC 10339. J. Nat. Prod. 2014, 77, 1871-1880. [CrossRef]

46. Luo, S.; Kang, H.-S.; Krunic, A.; Chen, W.-L.; Yang, J.; Woodard, J.L.; Fuchs, J.R.; Hyun Cho, S.; Franzblau, S.G.; Swanson, S.M.; et al. Trichormamides C and D, antiproliferative cyclic lipopeptides from the cultured freshwater cyanobacterium cf. Oscillatoria sp. UIC 10045. Bioorg. Med. Chem. 2015, 23, 3153-3162. [CrossRef] [PubMed]

47. Maru, N.; Ohno, O.; Uemura, D. Lyngbyacyclamides A and B, novel cytotoxic peptides from marine cyanobacteria Lyngbya sp. Tetrahedron Lett. 2010, 51, 6384-6387. [CrossRef]

48. Zhaxybayeva, O.; Gogarten, J.P.; Charlebois, R.L.; Doolittle, W.F.; Papke, R.T. Phylogenetic analyses of cyanobacterial genomes: Quantification of horizontal gene transfer events. Genome Res. 2006, 16, 1099-1108. [CrossRef]

49. Sitachitta, N.; Williamson, R.T.; Gerwick, W.H. Yanucamides A and B, two new depsipeptides from an assemblage of the marine cyanobacteria Lyngbya majuscula and Schizothrix species. J. Nat. Prod. 2000, 63, 197-200. [CrossRef]

50. Luesch, H.; Pangilinan, R.; Yoshida, W.Y.; Moore, R.E.; Paul, V.J. Pitipeptolides A and B, new cyclodepsipeptides from the marine cyanobacterium Lyngbya majuscula. J. Nat. Prod. 2001, 64, 304-307. [CrossRef]

51. Montaser, R.; Paul, V.J.; Luesch, H. Pitipeptolides C-F, antimycobacterial cyclodepsipeptides from the marine cyanobacterium Lyngbya majuscula from Guam. Phytochemistry 2011, 72, 2068-2074. [CrossRef]

52. Tripathi, A.; Puddick, J.; Prinsep, M.R.; Lee, P.P.F.; Tan, L.T. Hantupeptin A, a cytotoxic cyclic depsipeptide from a Singapore collection of Lyngbya majuscula. J. Nat. Prod. 2009, 72, 29-32. [CrossRef] [PubMed]

53. Tripathi, A.; Puddick, J.; Prinsep, M.R.; Lee, P.P.F.; Tan, L.T. Hantupeptins B and C, cytotoxic cyclodepsipeptides from the marine cyanobacterium Lyngbya majuscula. Phytochemistry 2010, 71, 307-311. [CrossRef] [PubMed]

54. Tripathi, A.; Puddick, J.; Prinsep, M.R.; Rottmann, M.; Tan, L.T. Lagunamides A and B: Cytotoxic and antimalarial cyclodepsipeptides from the marine cyanobacterium Lyngbya majuscula. J. Nat. Prod. 2010, 73, 1810-1814. [CrossRef] [PubMed]

55. Tripathi, A.; Puddick, J.; Prinsep, M.R.; Rottmann, M.; Chan, K.P.; Chen, D.Y.-K.; Tan, L.T. Lagunamide C, a cytotoxic cyclodepsipeptide from the marine cyanobacterium Lyngbya majuscula. Phytochemistry 2011, 72, 2369-2375. [CrossRef] [PubMed]

56. Boudreau, P.D.; Byrum, T.; Liu, W.-T.; Dorrestein, P.C.; Gerwick, W.H. Viequeamide A, a cytotoxic member of the kulolide superfamily of cyclic depsipeptides from a marine button cyanobacterium. J. Nat. Prod. 2012, 75, 1560-1570. [CrossRef] [PubMed]

57. Nakao, Y.; Yoshida, W.Y.; Szabo, C.M.; Baker, B.J.; Scheuer, P.J. More peptides and other diverse constituents of the marine mollusk Philinopsis speciosa. J. Org. Chem. 1998, 63, 3272-3280. [CrossRef]

58. Montaser, R.; Abboud, K.A.; Paul, V.J.; Luesch, H. Pitiprolamide, a proline-rich dolastatin 16 analogue from the marine cyanobacterium Lyngbya majuscula from Guam. J. Nat. Prod. 2011, 74, 109-112. [CrossRef] [PubMed] 
59. Engene, N.; Gunasekera, S.P.; Gerwick, W.H.; Paul, V.J. Phylogenetic inferences reveal a large extent of novel biodiversity in chemically rich tropical marine cyanobacteria. Appl. Environ. Microb. 2013, 79, 1882-1888. [CrossRef]

60. Jones, A.C.; Monroe, E.A.; Podell, S.; Hess, W.R.; Klages, S.; Esquenazi, E.; Niessen, S.; Hoover, H.; Rothmann, M.; Lasken, R.S.; et al. Genomic insights into the physiology and ecology of the marine filamentous cyanobacterium Lyngbya majuscula. Proc. Natl. Acad. Sci. USA 2011, 108, 8815-8820. [CrossRef] [PubMed]

61. Engene, N.; Choi, H.; Esquenazi, E.; Rottacker, E.C.; Ellisman, M.H.; Dorrestein, P.C.; Gerwick, W.H. Underestimated biodiversity as a major explanation for the perceived rich secondary metabolite capacity of the cyanobacterial genus Lyngbya. Environ. Microbiol. 2011, 13, 1601-1610. [CrossRef] [PubMed]

62. Engene, N.; Rottacker, E.C.; Kaštovský, J.; Byrum, T.; Choi, H.; Ellisman, M.H.; Komárek, J.; Gerwick, W.H. Moorea producens gen. nov., sp. nov. and Moorea bouillonii comb. nov., tropical marine cyanobacteria rich in bioactive secondary metabolites. Int. J. Syst. Evol. Microbiol. 2012, 62, 1171-1178. [CrossRef]

63. MarinLit. Available online: http://pubs.rsc.org/marinlit/ (accessed on 25 August 2019).

64. Clark, B.R.; Engene, N.; Teasdale, M.E.; Rowley, D.C.; Matainaho, T.; Valeriote, F.A.; Gerwick, W.H. Natural products chemistry and taxonomy of the marine cyanobacterium Blennothrix cantharidosmum. J. Nat. Prod. 2008, 71, 1530-1537. [CrossRef]

65. Gbankoto, A.; Vigo, J.; Dramane, K.; Banaigs, B.; Aina, E.; Salmon, J.-M. Cytotoxic effect of laxaphycins A and $\mathrm{B}$ on human lymphoblastic cells (CCRF-CEM) using digitised videomicrofluorometry. In Vivo 2005, 19, 577-582.

66. Yasumoto, T. Fish poisoning due to toxins of microalgal origins in the Pacific. Toxicon 1998, 36, 1515-1518. [CrossRef]

67. Ito, E.; Satake, M.; Yasumoto, T. Pathological effects of lyngbyatoxin A upon mice. Toxicon 2002, 40, 551-556. [CrossRef]

68. Schwarz, D.; Orf, I.; Kopka, J.; Hagemann, M. Recent applications of metabolomics toward cyanobacteria. Metabolites 2013, 3, 72-100. [CrossRef] [PubMed]

69. Réveillon, D.; Tunin-Ley, A.; Grondin, I.; Othmani, A.; Zubia, M.; Bunet, R.; Turquet, J.; Culioli, G.; Briand, J.-F. Exploring the chemodiversity of tropical microalgae for the discovery of natural antifouling compounds. J. Appl. Phycol. 2019, 31, 319-333. [CrossRef]

70. Aysun, A.; Yağmur, K.; Yusuf, B. Cell proliferation and cytotoxicity assays. Curr. Pharm. Biotechnol. 2016, 17, 1213-1221. [CrossRef] 